INTERNATIONAL JOURNAL OF SYSTEMATIC BACTERIOLOGY

Vol. 17, No. 2

April 1967

Page 229

\title{
A RECOMMENDATION TO THE EDITORS OF MICROBIOLOGICAL JOURNALS
}

In accordance with the International Code of Nomenclature of Bacteria, and as a unanimously passed resolution of the Judicial Commission of the International Committee on Nomenclature of Bacteria (ICNB), the IAMS Executive Council has been asked to submit to the member countries of IAMS the following recommendation:

Because the date of publication of the name of a new taxon of bacteria is the date when the printed matter becomes generally available, i. e. when the printed matter is placed in the mail, the member societies of IAMS are asked to encourage all editors of microbiological papers in their country to include in each issue of their publications the date when the previous issue was placed in the mail.

W. A. Clark - H. P. R. Seeliger

Permanent Secretaries, International Committee on Nomenclature of Bacteria 